\title{
KOMPOSISI DAN DISTRIBUSI LARVA NYAMUK Aedes PADA DAERAH ENDEMIS DEMAM BERDARAH DENGUE DI KOTA PEKANBARU
}

\author{
Novia Gesriantuti, Yeeri Badrun, Nurul Fadillah \\ Program Studi Biologi, Fakultas MIPA dan Kesehatan \\ Universitas Muhammadiyah Riau \\ Jl. Tuanku Tambusai Ujung, Pekanbaru 28291, Riau \\ e-mail:noviagesriantuti@umri.ac.id
}

\begin{abstract}
ABSTRAK
Penelitian ini bertujuan untuk mengetahui komposisi dan distribusi larva Aedes berdasarkan tempat perindukannya. Penelitian dilakukan bulan April sampai Mei 2017 di RW 08 Kelurahan Tuah Karya, Pekanbaru. Pengambilan larva dilakukan dengan cara mengambil larva yang ditemukan pada tempat perindukan di dalam dan di luar rumah. Larva diidentifikasi menggunakan metode single larva method dengan mengamati setiap larva berdasarkan posisi istirahat yang berbeda. Pada penelitian ini ditemukan 2 jenis nyamuk vektor penyakit demam berdarah dengue yaitu Aedes aegypti, Aedes albopictus. Hasil penelitian menunjukkan bahwa dari 40 rumah yang diperiksa ditemukan 24 rumah yang positif larva Aedes dan dari 188 tempat penampungan air (TPA) yang diperiksa ditemukan 31 kontainer yang positif larva Aedes. Jumlah Aedes lebih banyak ditemukan pada tempat penampungan air (TPA) di luar rumah dibandingkan di dalam rumah. Kelimpahan larva Aedes albopictus yaitu sebanyak 6,54\%, sedangkan larva Aedes aegypti sebanyak 1,68\%. Keberadaan larva nyamuk Aedes albopictus berpotensial menjadi vektor penyakit DBD di Kelurahan Tuah Karya. Angka Bebas Jentik (ABJ) didapatkan sebesar 40\%, House Indeks $(\mathrm{HI})=60 \%$, Container Indeks $(\mathrm{CI})=16,49 \%$. Angka ini menunjukkan RW 08 Kelurahan Tuah Karya merupakan daerah yang memiliki risiko tinggi dalam penularan penyakit demam berdarah dengue.
\end{abstract}

Kata kunci: Aedes aegypti, Aedes albopictus, Distribusi, Komposisi, Tempat Perindukan

\section{PENDAHULUAN}

Penyakit demam berdarah dengue (DBD) sampai saat ini masih merupakan masalah kesehatan masyarakat di Provinsi Riau yang memerlukan perhatian serius dari semua pihak, mengingat penyakit ini sangat potensial untuk terjadi Kejadian Luar Biasa (KLB) dan merupakan ancaman bagi masyarakat luas (Dinas Kesehatan Propinsi Riau, 2013). Jumlah kasus DBD yang dilaporkan pada tahun 2014 penderita DBD se-Riau sebanyak 2.366, Incident Rate (IR) angka kesakitan DBD 38,23/100.000 penduduk, Case Fatality Rate (CFR) Angka Kematian 1,4\% (34) orang. Sementara, Data penderita DBD pada Dinas Kesehatan Riau tahun 2015, menunjukkan bahwa penderita DBD se-Riau sebanyak 2.675 penderita, IR 43,2/100.000 penduduk dengan CFR 0,6\% (16) orang.

Data yang diperoleh dari Dinas Kesehatan Kota Pekanbaru pada pekan kelima tahun 2016, ditemukan kasus DBD di seluruh kecamatan di Kota Pekanbaru. Lima (5) kecamatan yang paling banyak kasus DBD adalah Kecamatan Payung Sekaki (27 kasus), Tampan (19 kasus), Rumbai Pesisisr (19 kasus), Marpoyan Damai (14 kasus) dan Senapelan (13 kasus). Ada tiga kecamatan yang kini seluruh kelurahannya endemis yakni Payung Sekaki, Simpang Tiga, dan Tampan (Berita Riau Niaga, 2016). Pada awal tahun 2017, salah satu kelurahan yang termasuk daerah endemis DBD adalah Kelurahan Tuah Karya yang berada di Kecamatan Tampan (Dinkes Pekanbaru, 2017). Berdasarkan data pasien DBD di Puskesmas Tuah Karya tahun 2017, jumlah kasus DBD terbanyak di RW 08/ RT 01 dan 02 yaitu sebanyak 4 kasus.

Penyakit DBD disebabkan oleh virus dengue dengan vektor utama nyamuk Aedes aegypti dan vektor potensialnya adalah Aedes albopictus yang banyak ditemukan di dalam maupun di luar rumah pada berbagai tempat penampungan air. Pengendalian vektor penyebab DBD masih diandalkan karena sampai hari ini belum ditemukan obatnya. Habitat nyamuk Aedes spp. yang dekat dengan tempat tinggal meningkatkan kemungkinan kontak dengan manusia.

Penyebaran nyamuk Aedes sangat luas dari wilayah perkotaan hingga ke pelosok pedesaan, disamping itu sangat mudah berkembang biak terutama dilingkungan sekitar tempat manusia beraktivitas. Tempat perindukannya juga sangat bervariasi, tetapi umumnya lebih menyukai 
berbagai macam tempat penampungan air jernih yang banyak terdapat di sekitar pemukiman penduduk, seperti bak mandi, tempayan dan barang-barang bekas yang menampung sisa-sisa hujan.

Hasil penelitian dari Wati (2015), di Dusun Krapyak Kulon dari jumlah TPA (Tempat Penampungan Air) yang positif jentik $A$. aegypti yang paling banyak terdapat di bak mandi dari 103 kontainer diperiksa ditemukan 24 positif larva A. aegypti dan pada kaleng bekas dari 76 kontainer ditemukan 2 positif larva $A$. albopictus. Hasyimi et al (2009), populasi vektor penyakit DBD dapat diketahui dengan cara penangkapan nyamuk dewasa, dengan koleksi jentik atau menggunakan perangkap telur ovitrap (terutama untuk daerah yang kepadatan nyamuknya rendah sehingga sulit ditemukan). Hasil penelitian dari Agustina (2013), menunjukkan bahwa air terpolusi dapat menjadi tempat perindukan dan berkembangbiaknya nyamuk $A$. aegypti. Jacob et al (2014), menyatakan air got yang didiamkan dan jernih menjadi tempat perindukan yang baik bagi Aedes spp. sehingga keberadaannya perlu diperhatikan dalam pembersihan sarang nyamuk. Hal ini diduga bahwa nyamuk Aedes spp. sudah mulai mulai beradaptasi pada berbagai jenis habitat.

Hasil penelitian dari Adifian et al (2013), menunjukan bahwa kemampuan adaptasi berkembang biak jenis $A$. aegypti pada air hujan larva sebesar $13.12 \%$ dan pupa sebesar $16.66 \%$, pada air sumur gali larva sebesar $16.54 \%$ dan pupa sebesar $33.32 \%$, pada air selokan larva sebesar $35.35 \%$ dan pupa sebesar $23.66 \%$. Kemampuan adaptasi berkembang biak jenis $A$. albopictus pada air hujan, larva sebesar $13.88 \%$ dan pupa sebesar $31.03 \%$, pada air sumur gali larva sebesar $9.33 \%$ dan pupa sebesar $16.16 \%$ dan pada air selokan larva sebesar $43.28 \%$ dan pupa sebesar $21.44 \%$.

Pada hasil penelitian Adifian et al (2013) dan Agustina (2013), dapat juga diambil kesimpulan bahwa larva Aedes spp. juga ditemukan pada selokan atau tempat tergenang yang sudah tercemar. Kedua tempat perindukan tersebut bukan merupakan habitat utama bagi nyamuk Aedes spp. Berdasarkan latar belakang di atas, sebagai langkah awal perlu diteliti bagaimana komposisi dan distribusi tempat perindukan dari nyamuk Aedes spp. pada daerah endemis penyakit DBD, sehingga nanti diharapkan bisa menjadi dasar untuk penelitian selanjutnya.

Nyamuk vektor penyebab DBD di Indonesia adalah $A$. aegypty dan $A$. albopictus. Kedua jenis nyamuk ini mempunyai daerah distribusi geografis sendiri-sendiri yang terbatas. Tempat perindukan nyamuk Aedes umumnya lebih menyukai berbagai macam tempat penampungan air jernih yang banyak terdapat di sekitar pemukiman penduduk, seperti bak mandi, tempayan dan barang-barang bekas yang menampung sisa-sisa hujan. Pada beberapa penelitian nyamuk $A$. albopictus ditemukan juga pada selokan yang airnya tergenang serta kotor. Komposisi dan distribusi perindukan nyamuk vektor DBD pada daerah endemis akan mempengaruhi penularan DBD. Upaya pengendalian nyamuk Aedes biasanya dilakukan langsung pada tempat perindukan sehingga diperlukan penelitian yang bertujuan untuk mendapatkan informasi tentang komposisi dan distribusi tempat perindukan nyamuk Aedes pada suatu daerah endemis.

Hasil yang didapatkan dari penelitian ini diharapkan memberikan informasi tentang jenisjenis dan distribusi perindukan nyamuk Aedes. Data distribusi perindukan nyamuk Aedes dapat dimanfaatkan dalam pemilihan cara pengendalian nyamuk Aedes. Apabila didapat hasil distribusi tempat perindukan yang beragam maka dapat juga dijadikan dasar penelitian selanjutnya untuk melihat perbedaan morfologi nyamuk Aedes. yang berasal dari tempat perindukan yang berbeda.

\section{METODOLOGI PENELITIAN Pengambilan Larva di Lapangan}

Populasi pada penelitian ini diperoleh dari larva nyamuk yang ada di Kelurahan Tuah Karya dan sampel penelitian adalah larva nyamuk yang diambil secara multistage sampling pada tempat perindukan di rumah warga. Pada penelitian ini ditetapkan 40 rumah untuk pengambilan data. Pada masing-masing RT ditetapkan sebanyak 10 rumah, penentuan rumah menggunakan 
purposive sampling yang ditentukan berdasarkan kondisi rumah yang berpotensi sebagai tempat perindukan bagi nyamuk Aedes yaitu terdapat banyak tumpukan sampah, genangan sisa air hujan, saluran air disekitar rumah tidak mengalir dan lain-lain.

Pengambilan larva dilakukan dengan cara mengambil larva yang ditemukan pada tempat perindukan di dalam dan di luar rumah. Untuk memeriksa tempat penampungan air (TPA) yang berukuran besar seperti bak mandi, ban bekas dan bak penampungan air lainnya, jika pada penglihatan pertama tidak ditemukan larva, tunggu kira-kira satu menit untuk memastikan bahwa larva benar-benar tidak ada. Untuk memeriksa tempat berkembangbiak yang kecil seperti penampungan sisa air dispenser, pot bunga dan botol, maka air didalamnya perlu dipindahkan ke tempat lain. Pemeriksaan larva di tempat yang agak gelap atau airnya keruh digunakan lampu senter

Larva yang diambil dimasukkan ke dalam gelas plastik, kemudian diberi keterangan berupa tempat pengambilan dan tanggal pengambilan larva. Larva diambil setiap 4 hari sekali, selama tujuh kali pengambilan.

\section{Identifikasi Larva di Laboratorium}

Identifikasi larva menggunakan metode single larva method yaitu dengan mengamati setiap larva berdasarkan posisi istirahat yang berbeda, kemudian untuk masing-masing bentuk posisi istirahat diambil satu larva di setiap TPA lalu diidentifikasi. Larva diamati dengan cara melihat morfologi larva di bawah mikroskop dengan perbesaran 10 kali. Larva diidentifikasi menggunakan kunci identifikasi larva Aedes yaitu buku identifikasi oleh Andreadis et al., tahun 2005, Cutwa dan O'Meara (Photographic Guide To Common Mosquitoes Of Florida) dan Depkes RI (2008)

Analisis data mengikuti beberapa formula berikut yaitu:

\section{Kelimpahan Nisbi $=$}

$\frac{\sum \text { individu nyamuk Aedes spesies tertentu }}{\text { total jumlah spesies nyamuk yang diperoleh }} \times 100 \%$

\section{Angka Bebas Jentik (ABJ)}

$\frac{\sum \text { rumah tidak ditemukan larva Aedes }}{\sum \text { rumah diperiksa }} \times 100 \%$

\section{House Indeks (HI)}

$\frac{\sum \text { rumah dengan larva Aedes }}{\sum \text { rumah diperiksa }} \times 100 \%$

\section{Container Indeks (CI)}

$\frac{\sum \text { tempat perindukan dengan larva Aedes }}{\sum \text { tempat perindukan diperiksa }} \times 100 \%$

\section{HASIL DAN PEMBAHASAN \\ Distribusi dan Kelimpahan Larva Nyamuk}

Pada penelitian ini ditemukan 3 spesies larva nyamuk yaitu: Aedes aegypti, Aedes albopictus dan Culex spp. Distribusi dan kelimpahan masing-masing larva nyamuk dapat dilihat pada Tabel 2.1.

Tabel 2.1 Distribusi dan Kelimpahan Larva Nyamuk di Kelurahan Tuah Karya

\begin{tabular}{|c|c|c|c|c|c|c|c|}
\hline \multirow{2}{*}{ Parameter } & \multirow{2}{*}{ Lokasi } & \multirow{2}{*}{ Larva } & \multicolumn{4}{|c|}{ Jumlah Larva } & \multirow{2}{*}{ Total } \\
\hline & & & RT 01 & RT 02 & RT 03 & RT 04 & \\
\hline \multirow{9}{*}{ Distribusi } & \multirow{3}{*}{$\begin{array}{l}\text { Dalam } \\
\text { rumah }\end{array}$} & Aedes aegypti & 4 & 4 & 19 & 0 & 27 \\
\hline & & Aedes albopictus & 0 & 0 & 0 & 0 & 0 \\
\hline & & Culex spp. & 0 & 0 & 47 & 0 & 47 \\
\hline & \multicolumn{6}{|c|}{ Jumlah } & 74 \\
\hline & \multirow{3}{*}{$\begin{array}{l}\text { Luar } \\
\text { rumah }\end{array}$} & Aedes aegypti & 0 & 0 & 0 & 0 & 0 \\
\hline & & Aedes albopictus & 3 & 60 & 14 & 28 & 105 \\
\hline & & Culex spp. & 270 & 416 & 740 & 0 & 1426 \\
\hline & \multicolumn{6}{|c|}{ Jumlah } & 1531 \\
\hline & \multicolumn{2}{|c|}{ Aedes aegypti } & 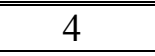 & 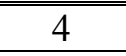 & 19 & 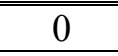 & 27 \\
\hline
\end{tabular}




\begin{tabular}{|c|c|c|c|c|c|c|c|}
\hline \multirow{4}{*}{$\begin{array}{c}\text { Parameter } \\
\text { Kelimpahan } \\
\text { Individu }\end{array}$} & \multirow{2}{*}{ Lokasi } & \multirow{2}{*}{ Larva } & \multicolumn{4}{|c|}{ Jumlah Larva } & \multirow{2}{*}{ Tota } \\
\hline & & & RT 01 & RT 02 & RT 03 & RT 04 & \\
\hline & \multicolumn{2}{|c|}{ Aedes albopictus } & 3 & 60 & 14 & 28 & 105 \\
\hline & & spp. & 270 & 416 & 787 & 0 & 1473 \\
\hline \multicolumn{7}{|c|}{ Total seluruh spesies } & 1605 \\
\hline \multirow{3}{*}{$\begin{array}{c}\text { Kelimpahan } \\
\text { Nisbi } \\
(\%) \\
\end{array}$} & \multicolumn{2}{|c|}{ Aedes aegypti } & 0,25 & 0,25 & 1,18 & 0 & 1,68 \\
\hline & \multicolumn{2}{|c|}{ Aedes albopictus } & 0,19 & 3,74 & 0,87 & 1,74 & 6,54 \\
\hline & \multicolumn{2}{|c|}{ Culex spp. } & 16,82 & 25,92 & 49,04 & 0 & 91,78 \\
\hline
\end{tabular}

Berdasarkan Tabel 4.2 dapat dilihat bahwa distribusi larva A. aegypti di RT 03 lebih tinggi dibandingkan RT yang lain yaitu sebanyak 19 ekor, hal ini dikarenakan banyak terdapat tempat penampungan air (TPA) yang berpotensi sebagai tempat perindukan (Tabel 4.3). Berdasarkan pengamatan, kurangnya kesadaran masyarakat membersihkan dan menutup TPA yang ada di dalam rumah seperti tempat penampungan air pada dispenser yang tidak rutin dibersihkan menjadi tempat nyamuk untuk meletakkan telurnya. Menurut Sallata et al., (2014), larva $A$. aegypti yang ditemukan ada hubungannya juga dengan makanan larva yang tersedia, karena ketersediaan makanan berkaitan dengan tempattempat penampungan air (TPA) yang ada di dalam rumah. Faktor lain yang mempengaruhi distribusi larva $A$. aegypti adalah padatnya rumah penduduk di RT 03. Menurut Budiyanto et al., (2005), A. aegypti banyak ditemukan di rumah yang padat penghuni, karena dengan demikian ada banyak kemungkinan nyamuk-nyamuk ini bisa mendapatkan nutrisi yang mereka butuhkan, seperti darah manusia.

Larva A. aegypti dan Culex spp. sama sekali tidak ditemukan di RT 04. Hal ini dipengaruhi oleh kondisi di dalam rumah yang bersih dibandingkan RT lainnya. Tingginya kesadaran masyarakat untuk menerapkan kebersihan misalnya tidak menampung air di dalam rumah sehingga tidak ada tempat yang terbuka untuk nyamuk $A$. aegypti meletakkan telurnya. Selanjutnya kebiasaan masyarakat untuk menggunakan anti nyamuk sehingga nyamuk menghindar dari tempat tersebut. Hasil ini didukung oleh data ada atau tidaknya yang terkena DBD di RT 04. Penelitian Erdinal et al., (2006), tentang faktor-faktor yang berhubungan dengan kejadian malaria di Kecamatan Kampar
Kiri Tengah diperoleh hasil responden yang tidur pada malam hari tidak memakai obat anti nyamuk mempunyai risiko 2,3 kali untuk terkena malaria dibandingkan dengan responden yang menggunakan obat anti nyamuk di waktu tidur. Hasil yang sama juga diperoleh Andriani (2012), yang menemukan bahwa adanya resiko kebiasaan tidak menggunakan obat anti nyamuk dengan terjadinya infeksi virus dengue di Semarang sebanyak 5,6 kali lebih besar.

Pada penelitian ini kelimpahan larva $A$. albopictus lebih tinggi di RT 02 yaitu sebanyak 60 ekor, hal ini disebabkan banyaknya tempat perindukan di sekitar rumah seperti ban bekas dan wadah bekas cat yang dijadikan sebagai tempat perindukan bagi nyamuk A. albopictus. Berdasarkan pengamatan, curah hujan juga mempengaruhi jumlah TPA yang ada di lokasi penelitian. Menurut Ishak et al., (2014), musim mempengaruhi jumlah kepadatan larva $A$. albopictus dikarenakan curah hujan berperan penting untuk tersedianya air sebagai tempat perindukan bagi nyamuk, disamping hal tersebut kelembaban mulai terlihat meningkat dan nyamuk menyukai tempat-tempat yang lembab sebagai tempat perindukan.

Jumlah larva $A$. albopictus yang terendah yaitu di RT 01 sebanyak 3 ekor. Sedikitnya jumlah TPA di sekitar rumah yang menjadi tempat perindukan larva A. albopictus merupakan faktor utama yang menyebabkan nyamuk tidak dapat menemukan tempat meletakkan telur. Wisfer et al., (2014), mengatakan bahwa rumah dengan banyak TPA memiliki peluang lebih besar dibandingkan rumah yang memiliki sedikit TPA terhadap keberadaan larva karena keberadaan TPA sangat berperan dalam kepadatan vektor nyamuk, semakin banyak TPA maka akan semakin banyak 
tempat perindukan dan akan semakin padat populasi nyamuk tersebut.

Berdasarkan Tabel 4.2 juga dapat dilihat kelimpahan dari masing-masing larva nyamuk yaitu Culex spp. sebanyak 91,78\%, kemudian larva A. albopictus sebanyak $6,54 \%$, sedangkan larva $A$. aegypti sebanyak $1,68 \%$. Larva $A$. albopictus hanya ditemukan di luar rumah didukung oleh keadaan di sekitar rumah warga banyak terdapat TPA yang berpotensi sebagai tempat perindukan bagi nyamuk A. albopictus. Selain itu juga, terdapat tanaman yang tidak terawat sehingga dijadikan sebagai tempat perindukan oleh nyamuk. Hal ini sesuai dengan pernyataan Hasan (2011), yang menyatakan bahwa nyamuk $A$. albopictus merupakan nyamuk yang mirip $A$. aegypti dengan tempat perindukan pada tempat penampungan air di dalam maupun di luar rumah dengan kecenderungan lebih sering di luar rumah. A. albopictus biasanya mencari makan dan bertelur di kebun, apabila ditemukan nyamuk ini di pemukiman karena lokasi rumah berada dekat dengan area kebun. Selanjutnya Thomas et al., (2006) juga menyatakan bahwa $A$. aegypti paling dominan terdapat di lokasi perumahan, sedangkan $A$. albopictus lebih sering ditemukan di daerah terbuka dengan banyak tanaman.

Larva $A$. aegypti hanya ditemukan di dalam rumah pada semua lokasi penelitian di Kelurahan Tuah Karya. Garjito (2012), menyatakan keberadaadn nyamuk di dalam rumah juga dipengaruhi oleh kondisi di dalam rumah yang cenderung lebih gelap sehingga udaranya cenderung lebih lembab. Hasil yang sama juga didapat dari penelitian Budiyanto (2012), yang melakukan penelitian pada Sekolah Dasar di Kabupaten Ogan Komering Ulu Sumatera Selatan diperoleh hasil nyamuk A. aegypti $100 \%$ ditemukan di dalam gedung.

Dilihat dari lebih banyaknya jumlah $A$. albopictus ditemukan maka diduga $A$. albopictus sebagai vektor penularan penyakit DBD di Kelurahan Tuah Karya. Hasil yang sama juga didapat dari penelitian Anwar (2014), tentang identifikasi dan distribusi nyamuk Aedes sp. sebagai vektor penyakit demam berdarah dengue di beberapa daerah di Sumatera Selatan diperoleh hasil hanya nyamuk $A$. albopictus yang ditemukan sedangkan nyamuk $A$. aegypti yang merupakan vektor utama DBD justru tidak berhasil ditemukan. Keberadaan nyamuk $A$. albopictus dapat dianggap sebagai salah satu indikator untuk mengantisipasi terjadinya kembali wabah dengue di Sumatera Selatan dikarenakan nyamuk tersebut sama-sama memiliki potensial menjadi vektor.

\section{Kepadatan Larva Nyamuk Aedes}

Berdasarkan hasil penelitian yang telah dilakukan di Kelurahan Tuah Karya pada 40 rumah dan 188 tempat penampungan air (TPA), ditemukan 24 rumah yang positif larva nyamuk Aedes dan 31 TPA yang positif larva nyamuk Aedes.

Tabel 2.2 Jumlah Rumah, Tempat Penampungan Air (TPA) dan Indeks ABJ, HI, CIdi Kelurahan Tuah Karya

\begin{tabular}{|c|c|c|c|c|c|c|}
\hline \multirow{2}{*}{ Objek } & \multicolumn{4}{|c|}{ Jumlah } & \multicolumn{3}{|c|}{ Indeks larva (\%) } \\
\cline { 2 - 7 } & Diperiksa & $\begin{array}{c}\text { Positif } \\
\text { larva Aedes }\end{array}$ & $\begin{array}{c}\text { Negatif larva } \\
\text { Aedes }\end{array}$ & ABJ & HI & CI \\
\hline Rumah & 40 & 24 & 16 & 40 & 60 & \\
\hline $\begin{array}{c}\text { Tempat } \\
\text { penampungan air } \\
\text { (TPA) }\end{array}$ & 188 & 31 & 166 & - & - & 16,49 \\
\hline
\end{tabular}

Tabel 4.3 menunjukkan bahwa Angka Bebas Jentik (ABJ) di Kelurahan Tuah Karya adalah sebesar $40 \%$, hal ini menunjukkan daerah tersebut memiliki risiko tinggi dalam penularan penyakit demam berdarah dengue (WHO dalam Santoso dan Budiyanto, 2008). Penyebabnya dikarenakan kondisi disekitar rumah terdapat tempat penampungan air (TPA) yang jarang diperiksa dan dibersihkan sehingga menjadi tempat perindukan bagi larva nyamuk. Taufan (2004), menjelaskan perilaku masyarakat untuk menampung air, tidak menguras bak mandi 
secara teratur dan membuang barang bekas yang dapat menampung air juga memempengaruhi keberadaan nyamuk Aedes. Penelitian yang telah pernah dilakukan Zulkarnaini (2009), tentang hubungan kondisi sanitasi lingkungan rumah tangga dengan keberadaan jentik vektor dengue di daerah rawan Demam Berdarah Dengue di Kota Dumai pada Tahun 2008 diperoleh hasil Angka Bebas Jentik ( ABJ) sebesar 1,97\%. Selanjutnya Nadifah (2015), tentang identifikasi larva nyamuk pada tempat penampungan air di Padukuhan Dero Condong Catur Kabupaten Sleman diperoleh Angka Bebas Jentik (ABJ) sebesar 56\%. Angka bebas jentik (ABJ) ini jauh dibawah indikator keberhasilan kegiatan pemberantasan sarang nyamuk demam berdarah dengue yaitu minimal $95 \%$.

Angka House Indeks (HI) di Kelurahan Tuah Karya sebesar $60 \%$ menunjukkan bahwa populasi rumah yang terdapat larva nyamuk penularan penyakit demam berdarah dengue dengan risiko tinggi (WHO dalam Santoso dan Budiyanto, 2008). Hal ini dikarenakan pemukiman penduduk di Kelurahan Tuah Karya yang padat sehingga memudahkan nyamuk untuk berpindah dari satu rumah ke rumah lainnya. Ramadhani dan Astuty (2013), mengatakan kepadatan penduduk dikaitkan dengan jarak terbang nyamuk dan penularan penyakit DBD. Hal ini disebabkan karena semakin padat penduduk maka semakin mudah untuk terjadinya penularan DBD oleh karena jarak terbang nyamuk diperkirakan sekitar 40-50 m.

Angka Container Indeks (CI) di Kelurahan Tuah Karya sebesar 16,49\%. Angka tersebut tergolong tinggi (WHO dalam Santoso dan Budiyanto, 2008), dikarenakan kondisi pemukiman banyak terdapat tempat perindukan nyamuk yang potensial seperti dispenser, wadah bekas cat yang menampung air hujan, ember plastik, ban bekas dan tempat penampungan air lainnya yang tidak diperhatikan sehingga vektor mudah berkembangbiak. Nadifah (2015), menjelaskan TPA yang menampung banyak air dapat membuat permukaan menjadi gelap sehingga memberikan rasa nyaman dan nyaman bagi nyamuk untuk meletakkan telurnya. Angka Container Indeks di Kelurahan Tuah Karya ini lebih rendah dibandingkan penelitian Arifudin (2014), di Kelurahan Kuranji, Kecamatan Kuranji Kotamadya Padang yaitu dengan ratarata 34,38\% yang tergolong tinggi. Angka CI di atas $10 \%$ artinya suatu wilayah sangat potensial bagi penyebaran penyakit demam berdarah.

Hasil penelitian kepadatan larva di Kelurahan Tuah Karya didapatkan Angka Bebas Jentik $(\mathrm{ABJ})=40 \%$, House Indeks $(\mathrm{HI})=60 \%$, Container Indeks $(\mathrm{CI})=16,49 \%$ tergolong pada risiko tinggi penularan DBD. Menurut Depkes tahun 2005, suatu wilayah dikatakan risiko tinggi untuk penularan $\mathrm{DBD}$ jika $\mathrm{ABJ} \leq 95 \%, \mathrm{HI} \geq 10 \%$, dan $\mathrm{CI} \geq 5 \%$.

Distribusi Larva Aedes Berdasarkan Letak Tempat Penampungan Air (TPA)

Berdasarkan hasil penelitian didapatkan larva Aedes lebih tinggi ditemukan di luar rumah dibandingkan di dalam rumah.

Tabel 4.4. Jumlah Larva Aedes Berdasarkan Letak TPA di Dalam/di Luar Rumah di Kelurahan

Tuah Karya

\begin{tabular}{|c|c|c|c|c|c|c|c|}
\hline \multirow{2}{*}{ No. } & \multirow{2}{*}{ RT } & \multicolumn{2}{|c|}{ Dalam Rumah } & \multirow{2}{*}{$C I$ dalam } & \multicolumn{2}{|c|}{ Luar Rumah } & \multirow{2}{*}{ CI luar } \\
\hline & & Diperiksa & $(+)$ & & Diperiksa & $(+)$ & \\
\hline 1 & RT 01 & 17 & 2 & 1,06 & 20 & 1 & 0,53 \\
\hline 2 & RT 02 & 15 & 1 & 0,53 & 38 & 10 & 5,32 \\
\hline 3 & RT 03 & 12 & 6 & 3,19 & 43 & 4 & 2,13 \\
\hline 4 & RT 04 & 7 & 0 & 0,00 & 36 & 7 & 3,72 \\
\hline \multicolumn{2}{|c|}{ Jumlah } & 51 & 9 & 4,78 & 137 & 22 & 11,60 \\
\hline \multicolumn{8}{|c|}{188} \\
\hline
\end{tabular}

Tabel 4.4 di atas menunjukkan distribusi larva nyamuk Aedes berdasarkan letak TPA di dalam dan di luar rumah. Kepadatan larva lebih tinggi di luar rumah $(11,60 \%)$ dibandingkan di 
dalam rumah (4,78\%). Hal ini memperlihatkan bahwa vektor DBD di Kelurahan Tuah Karya lebih menyukai tempat perindukan di luar rumah dibandingkan di dalam rumah, ini dikarenakan banyaknya tempat perindukan yang disukai nyamuk, seperti kondisi disekitar rumah terdapat penampungan air yang jarang diperiksa dan dibersihkan. Tempat penampungan air di dalam rumah juga cukup disenangi, hal ini karena kondisi air yang jernih, tidak mengalir dan terlindung dari cahaya matahari yang menjadikan suasana rumah sedikit gelap. Hasil ini didukung dengan ditemukannya $A$. albopictus lebih banyak di luar rumah daripada di dalam rumah (Tabel 4.2).

Angka Container Indeks yang tertinggi untuk di dalam rumah didapatkan pada RT 03 yaitu sebesar 3,19\%. Tingginya angka Container Indeks berhubungan dengan jumlah TPA yang ada di dalam rumah. Hal ini disebabkan karena masyarakat tidak menyadari bahwa TPA tersebut dapat menjadi tempat perindukan nyamuk. TPA yang ada dibiarkan begitu saja terisi air, tanpa dibersihkan. Kemudian, sebagian masyarakat yang kurang perduli untuk membersihkan tempat penampungan air seperti bak mandi dan genangan air secara rutin sehingga tempat-tempat penampungan air tersebut berpotensi sebagai tempat perkembangbiakan nyamuk Aedes.

Sementara itu, angka Container Indeks di dalam rumah yang terendah yaitu pada RT 04 sebesar $0,0 \%$. Hal ini dipengaruhi oleh tingkat pengetahuan masyarakat tentang pentingnya kesehatan sehingga memiliki perilaku untuk menjaga kebersihan TPA yang ada di dalam rumah. Dapat terlihat ditemukannya TPA yang dikelola dengan baik, sehingga tidak efektif sebagai tempat perindukan nyamuk. Sari (2012), mengatakan kebiasaan menguras dan rutin membersihkan tempat penampungan air merupakan salah satu pencegahan agar nyamuk Aedes tidak meletakkan telurnya.

RT 02 merupakan lokasi yang memiliki angka Container Indeks tertinggi di luar rumah. Hal ini dipengaruhi oleh jumlah TPA yang ditemukan di luar rumah seperti ban bekas, wadah bekas cat, botol bekas minuman dll yang berpotensi sebagai tempat perindukan. Keberadaan larva Aedes juga disebabkan jenis permukaannya yang kasar juga ditunjang oleh warnanya yang gelap. Menurut Sungkar (2007), TPA berwarna gelap lebih disukai sebagai tempat berkembang biak daripada yang berwarna terang. TPA berwarna gelap membuat nyamuk merasa aman dan tenang saat nyamuk bertelur sehingga telur yang diletakkan lebih banyak dan jumlah larva yang terbentuk juga lebih banyak.

Angka Container Indeks terendah di luar rumah yaitu di RT 01 . Kondisi rumah penduduk di RT 01 cukup sederhana, di sekitar rumah terdapat banyak tanaman yang tidak terawat sehingga disukai oleh nyamuk untuk beristirahat. Hal ini diduga karena walaupun di sekitar rumah terdapat banyak tanaman yang tidak terawat menjadi tempat yang disukai nyamuk untuk beristirahat tetapi tidak didukung oleh jumlah TPA yang ditemukan di luar rumah hanya sedikit sehingga nyamuk Aedes tidak dapat menemukan tempat perindukan untuk meletakkan telurrnya.

Jumlah Tempat Penampungan Air (TPA)yang Positif Larva

Pada Tabel 4.5 jumlah tempat penampungan air (TPA) yang positif larva Aedes berkisar $0-7$ buah.

Tabel 4.5 Jumlah TPA yang Ditemukan Larva di Kelurahan Tuah Karya.

\begin{tabular}{|c|c|c|c|}
\hline \multirow{2}{*}{ No. } & \multirow{2}{*}{ TPA } & \multicolumn{2}{c|}{ Jumlah TPA } \\
\cline { 3 - 4 } & & Jumlah diperiksa & Positif larva \\
\hline \multicolumn{2}{|c|}{ Tempat Penampungan Air (TPA) } \\
\hline 1 & Bak mandi & 8 & 0 \\
\hline 2 & Tempat minum burung & 4 & 0 \\
\hline 3 & Dispenser & 23 & 0 \\
\hline 4 & Kulkas & 2 & 1 \\
\hline 5 & Sumur semen & 1 & 0 \\
\hline 6 & Tempat mandi ayam & 40 & 1 \\
\hline 7 & Selokan & 1 & 1 \\
\hline
\end{tabular}




\begin{tabular}{|c|c|c|c|}
\hline \multicolumn{2}{|c|}{ Ember besar penampung air } & 1 & 0 \\
\hline \multicolumn{4}{|c|}{ Non Tempat Penampungan Air (TPA) } \\
\hline 10 & Kompor bekas & 1 & 0 \\
\hline 11 & Genangan air di dapur rumah & 4 & 1 \\
\hline 12 & Cup bekas aqua gelas & 2 & 1 \\
\hline 13 & Ban bekas & 23 & 5 \\
\hline 14 & Wadah bekas cat kecil & 32 & 1 \\
\hline 15 & Wadah bekas cat besar & 5 & 0 \\
\hline 16 & Skop sampah & 1 & 0 \\
\hline 17 & Kaleng bekas makanan & 2 & 2 \\
\hline 18 & Botol bekas minuman & 2 & 0 \\
\hline 19 & Bak mandi bekas & 5 & 0 \\
\hline 20 & Cup bekas teh gelas & 1 & 0 \\
\hline 21 & Tempat makanan ayam & 1 & 1 \\
\hline 22 & Baskom bekas & 1 & 4 \\
\hline 23 & Barang bekas keramik & 1 & 0 \\
\hline 24 & Vas bunga & 11 & 0 \\
\hline 25 & Batok kelapa & 1 & 31 \\
\hline 26 & Genangan air pada polybag & 2 & 188 \\
\hline
\end{tabular}

Berdasarkan Tabel 4.5 dapat dilihat bahwa, larva Aedes paling banyak ditemukan pada dispenser, hal ini diduga karena kebiasaan masyarakat tidak rutin membersihkan tempat pembuangan air dispenser yang tergenang sehingga dapat menyebabkan nyamuk meletakkan telurnya, dan warna TPA juga mempengaruhi kebiasaan nyamuk meletakkan telur. Hasil penelitian ini sejalan dengan penelitian yang di lakukan oleh Novelani (2007), yang menyatakan bahwa ternyata wadah yang positif larva lebih banyak di jumpai pada wadah berwarna biru $(41,7 \%)$.

\section{KESIMPULAN}

Larva nyamuk vektor penyakit demam berdarah yang ditemukan adalah Aedes albopictus dan Aedes aegypti. Keberadaan larva nyamuk Aedes albopictus berpotensial menjadi vektor penyakit DBD di Kelurahan Tuah Karya.

Distribusi larva nyamuk Aedes berdasarkan letak TPA di dalam dan di luar rumah, ditemukan kepadatan larva lebih tinggi di luar rumah yaitu $(11,60 \%)$, dibandingkan di dalam rumah $(4,78 \%)$.

Kepadatan larva nyamuk Aedes di Kelurahan Tuah Karya memiliki Angka Bebas Jentik (ABJ) $=40 \%$, House Indeks $(\mathrm{HI})=60 \%$, Container Indeks $(\mathrm{CI})=16,49 \%$, hal ini menunjukkan bahwa wilayah ini berisiko tinggi dalam terjadinya penularan DBD.

Kelurahan Tuah Karya merupakan daerah endemis penyakit demam berdarah, untuk itu perlu dilakukan uji resistensi nyamuk vektor Aedes aegypi dan Aedes albopictus untuk menunjang pengendalian atau pemberantasan nyamuk vektor penyebab demam berdarah yang efektif.

\section{DAFTAR PUSTAKA}

Adifian, Hasanuddin Ishak, Ruslan La Ane. 2013. Kemampuan Adaptasi Nyamuk Aedes aegypti dan Aedes albopictus Dalam Berkembang Biak Berdasarkan Jenis Air. Fakultas Kesehatan Masyarakat, UNHAS, Makassar.

Agustina, E.2013. Pengaruh Media Air Terpolusi Tanah Terhadap Perkembangbiakan Nyamuk Aedes aegypti. Jurnal Biotik, ISSN: 2337-9812, Vol. 1, No. 2, Ed. September 2013, Hal. 67-136

Andreadis G. Theodore, Thomas C. Michael dan Shepard J. John. 2005. Identification Guide To The Mosquitoes Of Connecticut. The Connecticut Agricultural Experiment Station. Bulletin No. 966

Andriani Sri. 2012. Perilaku Pencegahan Terhadap Gigitan Nyamuk Sebagai 
Faktor Risiko Terjadinya Infeksi Virus Dengue di Kota Semarang [Thesis]. Semarang: Universitas Diponegoro

Anwar Chairil, Rizki A. Lavita dan Dwi H. 2014. Identifikasi dan Distribusi Nyamuk Aedes Sp. Sebagai Vektor Penyakit Demam Berdarah Dengue di Beberapa Daerah di Sumatera Selatan. Jurnal $M K S$, Th. 46, No. 2

Arifudin M, Adrial dan Selfi R. R. 2014. Survey Larva Nyamuk Aedes Vektor Demam Berdarah Dengue di Kelurahan Kuranji Kecamatan Kuranji Kotamadya Padang Provinsi Sumatera Barat. Diakses dari http://jurnal.fk.unand.ac.id_pada tanggal 25 januari 2017

Berita Riau Niaga, 2016.
$\mathrm{http} / /$ berita.riauniaga.com/read/berita36779/nyaris-seluruh-kelurahan-dipekanbaru-riau-ada-kasus-dbd.php. diakses 20 Februari 2016.

Budiyanto Arif SKM, Santoso SKM, Dian purnama AMKL, R. Irpan pahlepi AMKI. 2005. Studi Indeks Larva Nyamuk Aedes Aegypti Dan Hubungannya Dengan Psp Masyarakat Tentang Penyakit DBD Di Kota Palembang Sumatera Selatan Tahun 2005. Dinas Kesehatan Palembang

Cutwa M. Michele and O'Meara F. George. Photographic Guide To Common Mosquitoes Of Florida. Florida Medical Entomology Laboratory. University of Florida

[Depkes RI] Departemen Kesehatan Republik Indonesia. 2008. Kunci Identifikasi Nyamuk Aedes. Jakarta: Direktorat Jendral Pengendalian Penyakit dan Penyehatan Lingkungan, Depar-temen Kesehatan RI.

Dinas Kesehatan Riau. 2013. Profil Kesehatan Propinsi Riau. Dinas Kesehatan Riau.

Dinas Kesehatan Provinsi Riau 2015 (Dinkes Riau). Profil Kesehatan Provinsi Riau 2015. Pekanbaru

Dinas Kesehatan Kota Pekanbaru 2017 (Dinkes Pekanbaru). Data Demam Berdarah Dengue (DBD). Pekanbaru
Erdinal, Dewi Susanna dan Ririn A. Wulandari. 2006. Faktor-Faktor yang Berhubungan Dengan Kejadian Malaria di Kecamatan Kampar Kiri Tengah. Jurnal MAKARA Kesehatan, Vol. 10, No. 2, hal 64-70

Garjito AT, Jastal, Rosmini Y, Wijaya Y dan Labatjo YS. Investigasi Tempat Perindukan Aedes aegypti (L) pada Tiga Daerah dengan Endemisitas yang Berbeda (Endemis, Sporadis dan Non Endemis) di Wilayah Kota Palu,Sulawesi Tengah. Jurnal Ekologi Kesehatan, 5 (2), 2006: hal 41742

Hasan Boesri. 2011. Biologi dan Peranan Aedes albopictus (Skuse) 1894 Sebagai Penular Penyakit. Balai Besar Penelitian dan Pengembangan Vektor dan Reservoir Penyakit Salatiga, Badan Litbangkes.

Hasyimi, M., Nanny H \& Pangestu. 2009. Tempat-Tempat Terkini Yang Disenangi Untuk Perkembangbiakan Vektor Demam Berdarah Aedes sp. Media Litbang Kesehatan 19 (2): 71-77

Ishak, H., Nurzidah, dan M. Selomo. 2014. Identifikasi nyamuk Anopheles sp. dewasa di wilayah endemis dan non endemis malaria kecamatan Bonto Bahari Bulukumbia Sulawesi Selatan. Laporan Penelitian. Bagian Kesehatan Lingkungan Fakultas Kesehatan Masyarakat Universitas Hasanuddin, Makassar.

Jacob, A., Victor D. Pijoh, G.J.P. Wahongan. 2014.Ketahanan Hidup dan Pertumbuhan Nyamuk Aedes spp Pada Berbagai Jenis Air Perindukan, Jurnal eBiomedik (eBM), Volume 2, Nomor 3.

Novelani. 2007. Studi Habitat dan Perilaku Menggigit Nyamuk Aedes Serta Kaitannya Dengan Kasus Demam Berdarah di Kelurahan Utan Kayu Utara Jakarta Timur.Tesis Dipublikasikan. Bogor Pascasarjana. Institut Pertanian Bogor

Nadifah, F., Nurlaili Farida Muhajir, Desto Arisandi1, Maria D. Owa Lobo. 2016. Identifikasi Larva Nyamuk Pada Tempat Penampungan Air Di Padukuhan Dero 
Condong Catur Kabupaten Sleman. Jurnal Kesehatan Masyarakat Andalas. Vol. 10, No. 2, Hal. 172-178.

Ramadhani, M. dan H. Astuty. 2013. Kepadatan dan penyebaran Aedes aegypti setelah penyuluhan DBD di Kelurahan Paseban, Jakarta Pusat. eJurnal Kedokteran Indonesia. 1(1): 10-14.

Sallata Meilson H.E., Erniwati Ibrahim dan Makmur Selomo. 2014. Hubungan Karakteristik Lingkungan Fisik dan Kimia Dengan Keberadaan Larva Aedes Aegypti di Wilayah Endemis DBD Kota Makassar. Fakultas Kesehatan Masyarakat Universitas Hasanuddin

Santoso dan Anif Budiyanto. 2008. Hubungan Pengetahuan Sikap dan Perilaku (PSP) Masyarakat Terhadap Vektor DBD di Kota Palembang Provinsi Sumatera Selatan. Jurnal Ekologi Kesehatan. Vol 7 No. 2 hal 732-739

Sari P., Martini dan Praba G. 2012. Hubungan Kepadatan Jentik Aedes Sp dan Praktik PSN Dengan Kejadian DBD di Sekolah Tingkat Dasar di Kota Semarang. Jurnal Kesehatan Masyarakat, Volume 1, Nomor 2, Halaman 413 - 422

Sungkar S. 2007. Pemberantasan Demam Berdarah Dengue: Sebuah Tantangan yang Harus Dijawab. Majalah Kedokteran Indonesia, Vol. 57, Nomor 6
Taufan F. Gambaran kepadatan vektor demam berdarah dengue di Bandar Purus Kodya Padang. (skripsi). Padang: Universitas Andalas; 2004.

Thomas S, Suharyono W \& Sri RH. 2006. Pencegahan dan Penanggulangan Penyakit Demam Dengue dan Demam Berdarah Dengue: Petunjuk Lengkap. Terjemahan WHO dan DEPKES RI. Jakarta: DEPKES RI.

Wati, Nur A.P. 2015. Survei Entomologi Dan Penentuan Maya Index Di Daerah Endemis DBD Di Dusun Krapyak Kulon, Desa Panggungharjo, Kecamatan Sewon, Kabupaten Bantul, D. I. Yogyakarta. Jurnal Medika Respati Volume X Nomor 3.

Wisfer, Erniwati Ibrahim, Makmur Selomo. 2014. Hubungan Jumlah Penghuni, Tempat Penampungan Air Keluarga Dengan Keberadaan Larva Aedes aegypti Di Wilayah Endemis DBD Kota Makassar. Fakultas Kesehatan Masyarakat Universitas Hasanudin.

Zulkarnaini, Yusni I. S. dan Dameri. 2009. Hubungan Kondisi Sanitasi Lingkungan Rumah Tangga dengan keberadaan Jentik Vektor Dengue di Daerah Rawan Demam Berdarah Dengue Kota Dumai Tahun 2008. Jurnal Ilmu Lingkungan. 2009. Vol. 2 No. 3 